\title{
SYNTHESIS OF ALLYLCAPRYLATE-STYRENE COPOLYMERS WITH STYROLE AND THEIR RESEARCH AS A VISCOSITY ADDITIVE TO LUBRICANT OILS
}

\author{
J.Sh. Hamidova, L.K. Kazimzade, E.I. Hasanova, E.U. Isakov, S.S. Babayev \\ Academician A.M.Guliyev Institute of Chemistry of Additives, \\ Beyukshor Highway, Block 2062, Baku, AZ1029 (+9912)5149612 \\ E-mail: c.hamidova@mail.ru
}

Received 06.02.2020.

Accepted 02.04.2020

\begin{abstract}
The article presents results of copolymerization of allyl ether of caprylic acid allylcaprylate with styrene in line with radical mechanism, the influence of the main factors - the composition of primary monomers and initiator consumption on the process, as well as results of studies synthesized copolymer as a viscosity additive in the composition of lubricating oils. It found that samples of synthesized polymer compounds are on a par with industrial additives of the polyalkylmethacrylate type on improving viscosity-temperature properties, but have higher operational characteristics than industrial additives in terms of resistance to thermal effects due to the stabilizing effect of styrene units. The study into samples of synthesized copolymers as oil additives showed that depending on specific requirement, a polymer compound of any molecular weight can be synthesized in high yield for use as viscosity additive for these oils.
\end{abstract}

Keywords: caprilic acid, allyl alcohol, allylcaprate, styrene, copolymer, viscosity additive, petroleum oil

DOI: 10.32737/2221-8688-2020-2-158-163

\section{Introduction}

Obtaining of basic oils with high viscosity index is one of the urgent problems of presentday oil chemistry. The higher the viscosity index value which characterizes viscositytemperature properties of oils, the lesser the viscosity of oils changes due to the effect of temperature and can be considered valuable. Viscosity-temperature properties of oils are determined with due regard for their chemical composition, purification degree, development level of production technology and so on. It is possible to obtain a required value of viscosity index by changing the above-mentioned factors. The simplest, economically profitable and rational way of oils production with high viscosity index is the use of petroleum oils viscosity additives comprising a small amount of polymer compounds, i.e. it is possible to achieve any result with the least material expenses.

Oil-soluble polymers and copolymers of polyisobuthylenes, polyalkylmethacrylates and other vinyl monomers are used as viscosity additives [1-4]. However, these additives meet no requirements of modern techniques on resistance to destructive effects.

The analysis of research works on the synthesis and study of polymethacrylate additives shows that obtaining of complex ether polymers are more promising than hydrocarbon type polymers, for they are obtained by simple technology and improve viscosity-temperature properties of oils more effectively. From this point of view, to expand the feedstock of monomers used for obtaining of viscosity additives complex allyl ethers were synthesized and certain researches were carried out to obtain synthetic and petroleum oils by polymerizing them with vinyl monomers [5-8].

The present paper explores results of experiments performed to obtain viscosity additives for petroleum oils using allyl monomers - allyl ether of caprilic acid (octanoic acid) - allylcaprylate.

As is known, allyl monomers are not polymerized separately; however, they easily 
enter into copolymerization reaction. That's why obtained monomers (allylcaprylate) were copolymerized with styrene. Styrene is one of the cheap monomers of oil chemistry and inclusion of styrene units into open chain polymer macromolecule gives stability to copolymers to thermal impacts.

\section{Experimental part}

Allylcaprylate is obtained by influencing caprilic acid with allyl alcohol through the wellknown etherification reaction.

Caprilic acid (octanoic acid) and allyl alcohol were taken as a reactive. Both acid and allyl alcohol are included into etherification reaction in a freshly distilled form. Physical and chemical properties of an acid: mol. mass $\mathrm{Mr}=$ 144.2, melting temperature $\mathrm{T}_{\text {melt. }}=16.63^{\circ} \mathrm{C}$, boiling temperature $\mathrm{T}_{\text {boil }} .=239.3^{\circ} \mathrm{C} / 760 \mathrm{~mm}$ $\left(124^{\circ} / 10 \mathrm{~mm}\right)$, refraction coefficient $n D=$ 1.4280 , density $\mathrm{d}_{4}{ }^{20}=0.99089 \mathrm{q} / \mathrm{cm}^{3}$, physical and chemical properties of allyl alcohol: mol. mass $\mathrm{Mr}=58.8$, melting temperature $\mathrm{T}_{\text {melt }}=-129^{\circ} \mathrm{C}$, boiling temperature $\mathrm{T}_{\text {boil }}=97^{\circ} \mathrm{C}$, refraction coefficient $n D=1.4133$, density $d 4 \AA=0.854 \mathrm{~g} / \mathrm{cm}^{3}$.

The reaction was methodically performed as follows. Calculated amount of reagents, certain amount of toluene (to separate water by azeotropic distillation), KU-2 cationite in the amount of $1 \%$ of reaction mixture were added to three necked flask supplied with DeanStark apparatus and the mixture was heated at $110-120^{\circ} \mathrm{C}$ temperature by mixing till water boiling:

$$
\begin{aligned}
& \mathrm{CH}_{3}\left(\mathrm{CH}_{2}\right)_{6} \mathrm{COOH}+\mathrm{CH}_{2}==\mathrm{CH}----\mathrm{CH}_{2} \mathrm{OH}------ \\
& -----\mathrm{CH}_{3}\left(\mathrm{CH}_{2}\right)_{6} \mathrm{COOCH}_{2} \mathrm{CH}=\mathrm{CH}_{2}+\mathrm{H}_{2} \mathrm{O}
\end{aligned}
$$

Upon completion of the process, KU-2 catalyst was separated from the filtering system, the product was washed off with hot water distilled in vacuum after traces of toluene and allyl alcohol were separated. Obtained allyl ether was used in copolymerization with styrene.

Synthesized allylcaprate ether had the following physical and chemical properties: $\mathrm{Mr}$ $=184, n D=1.4276, \mathrm{~d}_{4}{ }^{20}=0.909 \mathrm{~g} / \mathrm{cm}^{3}$.

Styrene was used as a chemical reagent in distilled form; its physical and chemical properties were as follows: $\mathrm{Mr}=104.15, n D=$ $1.5465, \mathrm{~d}^{20}=0.909 \mathrm{~g} / \mathrm{cm}^{3}$, melting temperature $\mathrm{T}_{\text {melt. }}=-30.06^{\circ} \mathrm{C}$, boiling temperature $\mathrm{T}_{\text {boil. }}=$ $145^{\circ} \mathrm{C}$.

\section{Results and discussion}

As Table 1 shows, the main factors influencing the process are the composition of primary monomer and amount of an initiator (Table 1). The rise of styrene in monomer mixture from $5 \%$ to $25 \%$ causes the increase in the yield of copolymer from $25.0 \%$ to $91.3 \%$ and molar mass from 3000 to 8000 . This is explained as being due to the fact that styrene has a high polymerization property and the rise
Copolymerization was performed in solution medium (hexane or heptane) with the presence of dinitrile of azo-(bis)-isooil acid as an initiator using radical polymerization mechanism. The effect of copolymerization condition on the properties of copolymer was studied and the results given in Table 1.

The composition and structure of synthesized compounds were studied using IRand NMR-spectroscopy methods.

Thermal resistance of synthesized copolymer was determined by reduction of viscosity depending on the probation occurring in $5 \%$ of solution in Turbin "L" oil using known technique [10].

in its amount in monomer mixture causes the process acceleration and the rise in yield and molar mass. Allyl monomers are not polymerized separately, i.e. form no homopolymers and enter into polymer chain due to copolymerization. Thus, amount of allyl monomers must not be higher than $50 \mathrm{~mol} \%$ and when the amount of it exceeds the given value the yield of copolymer and molar mass 
decrease. The increase of initiator amount from $0.3 \%$ to $1 \%$ raises the yield of copolymer, however causes the decreases of molar mass and this is typical for radical polymerization.

Table 1. Copolimerization of allylcaprylate with styrene

\begin{tabular}{|c|c|c|c|c|c|}
\hline \multicolumn{3}{|c|}{ Copolymerization condition } & \multicolumn{2}{c|}{$\begin{array}{c}\text { Character of } \\
\text { copolymerization }\end{array}$} \\
\hline $\begin{array}{c}\text { Amount of styrene } \\
\text { in monomer } \\
\text { mixture, mass \% }\end{array}$ & $\begin{array}{c}\text { Amount of } \\
\text { initiator, \% }\end{array}$ & $\begin{array}{c}\text { Duration of } \\
\text { process, hour }\end{array}$ & $\begin{array}{c}\text { Temperature } \\
\left({ }^{\circ} \mathrm{C}\right)\end{array}$ & $\begin{array}{c}\text { Yield, mass } \\
\%\end{array}$ & $\begin{array}{c}\text { Molar } \\
\text { mass }\end{array}$ \\
\hline 5 & & & & & \\
\hline 10 & 1 & 4 & 75 & 25.0 & 3000 \\
15 & 1 & 4 & 75 & 53.4 & 4000 \\
20 & 1 & 4 & 75 & 60.8 & 5000 \\
25 & 1 & 4 & 75 & 85.5 & 7000 \\
\hline 20 & 0.3 & 4 & 75 & 91.3 & 8000 \\
20 & 0.5 & 4 & 75 & 50.1 & 9000 \\
20 & 0.7 & 4 & 75 & 71.2 & 8000 \\
20 & 1 & 4 & 75 & 83.3 & 7500 \\
\hline 20 & 1 & 3 & 75 & 77.8 & 7000 \\
\hline 20 & 1 & 6 & 75 & 79.9 & 7100 \\
\hline 20 & 1 & 4 & 65 & 76.5 & 7200 \\
20 & 1 & 4 & 85 & 81.5 & 7000 \\
\hline
\end{tabular}

Temperature changes in the range of 65 $85^{\circ} \mathrm{C}$ and increase of polymerization duration do not influence the process sharply while an amount of initiator taken less than $1 \%$ causes the decrease in yield and increase in molar mass. That's why reaction conditions that provide the high yield and molar mass parameters can be selected as follows: temperature $75{ }^{0} \mathrm{C}$, process duration 4 hours, amount of an initiator for monomer mixture $1.0 \%$. The structure of synthesized copolymer was studied by IR- and NMR-spectroscopy methods and according to results obtained the following schematic general formula was proposed for obtained copolymers:

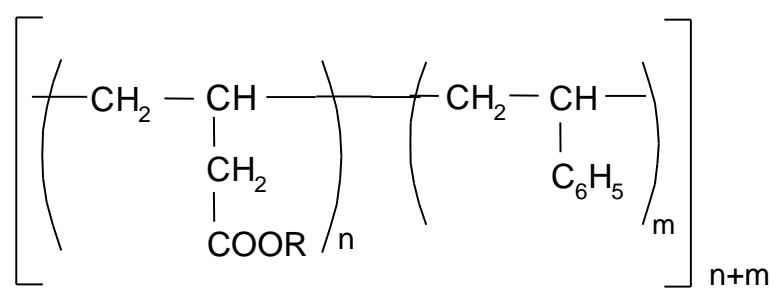

here $n=8-19, m=18-34, R$ - caprilic acid radical

Synthesized copolymer was studied as viscosity additive for lubricants. The impact of viscosity-temperature properties of $\mathrm{H}-12 \mathrm{~A}$ petroleum oil on copolymer density with molar mass of 8000 was studied and the results given in Table 2. 
Table 2. Impact of copolymer density on viscosity-temperature of H-12A oil

\begin{tabular}{|c|c|c|}
\hline $\begin{array}{c}\text { Density of copolymer, } \\
\text { mass } \%\end{array}$ & $\begin{array}{c}\text { Kinematic viscosity of oil } \\
\text { concentrated at } 100^{\circ} \mathrm{C}, \\
\mathrm{mm}^{2} / \mathrm{sec}\end{array}$ & Viscosity index (VI) \\
\hline 0 & 3.11 & 89 \\
0,5 & 3.67 & 104 \\
1 & 4.22 & 114 \\
2 & 5.53 & 132 \\
3 & 6.29 & 134 \\
5 & 8.03 & 136 \\
7 & 9.09 & 136 \\
\hline
\end{tabular}

As Table 2 shows, rise in the density of oil copolymer from $0.5 \%$ to $5 \%$ led to the increase in viscosity index (VI) from 89 to 138. Further increase in density $(7 \%)$ did not cause the increase of viscosity index and that was general regularity of concentrating oils. In considering that the demand VI for concentrated oils with viscosity of $8 \pm 0.5 \mathrm{~mm}^{2} / \mathrm{sec}$ at $100^{\circ} \mathrm{C}$ must not be less than 125 , according to Table 2, we may obtain oil with required properties by adding $5 \%$ of copolymer into $\mathrm{H}-12 \mathrm{~A}$ oil.

The influence of molar mass of synthesized copolymer on viscosity-temperature properties of $\mathrm{H}-12 \mathrm{~A}$ oil was studied. Oil was concentrated and studied with copolymer at $100^{\circ} \mathrm{C}$ till kinematic viscosity reached $7.5-8.5$ $\mathrm{mm}^{2} / \mathrm{sec}$. Results were summarized in Table 3 and all samples used to concentrate oil met the requirements for VI value. However, with the reduction of molar mass it is necessary to increase the amount of copolymer in oil content to achieve the required value of viscosity of oil and this is not economically effective. The increase in molar mass causes decreases resistance of copolymer in oil content to destructive effects. Molar mass value of copolymer to be used as a viscosity additive is selected relevant to a certain demand put for resistance of concentrated oil.

Table 3. Influence of molar mass of synthesized copolymer on viscosity-temperature properties of H-12A oil

\begin{tabular}{|c|c|c|c|}
\hline \multicolumn{3}{|c|}{ Characteristics } \\
\hline \multicolumn{3}{|c|}{ copolymer } & \multicolumn{2}{c|}{ concentrated oil } \\
\hline molar mass & density, $\%$ & $\begin{array}{c}\text { kinematic viscosity at } \\
100^{\circ} \mathrm{C}, \mathrm{MM}^{2} / \mathrm{C}\end{array}$ & viscosity index \\
\hline 10000 & 4.0 & 7.6 & 136 \\
9000 & 5.5 & 7.9 & 133 \\
8000 & 6.0 & 7.8 & 130 \\
5000 & 9.0 & 7.9 & 128 \\
3000 & 10.2 & 7.6 & 125 \\
\hline \multicolumn{4}{|c|}{ Polyalkyl methacrylate } \\
\hline
\end{tabular}

According to Table 3, examined samples are in the same level with industrial viscosity additive - polyalkylmethacrylate for improving viscosity-temperature properties of $\mathrm{H}-12 \mathrm{~A}$ oil.
Thermal resistance of synthesized copolymer samples was studied in comparison with known viscosity additives polyisobuthylene and polyalkylmethacrylate by 
heating their $5 \%$ solutions in turbine "L" oil at $200^{\circ} \mathrm{C}$ for 12 hours. It was determined that synthesized copolymer exhibits higher operating characteristics than polyalkylmethacrylate type industrial additives due to its resistance to thermal effects. For oil concentrated with copolymer the reduction of viscosity due to destruction is $7.0-7.5 \%$, and this indicator is into the range of $9.5-11.4$ and $13.7^{\wedge} 17.9 \%$ for polyisobuthylene and polyalkylmethacrylates, accordingly. These results show that the inclusion of cyclic aromatic fragment in styrene molecule into copolymer increases resistance of obtained macromolecular compound to thermal effects

\section{Conclusion}

Copolymers of allyl ether - raised the yield of copolymer, however, allylcaprylate of caprilic acid with styrene were obtained by means of radical copolyemrization. Also, the composition of primary monomers and amount of initiator - the main factors that influence the process were determined. It revealed that the rise in the styrene amount of monomer mixture caused the increase in yield of copolymer and molar mass. This was explained as being due to the fact that styrene had a high polymerization property and the increase in its amount in monomer mixture led to the process acceleration and increase in yield of molar mass. The amount of allyl monomers in copolymer of more than $50 \mathrm{~mol} \%$ reduced the yield of copolymer and molar mass. The increase of initiator amount from $0.3 \%$ to $1 \%$ decreased the molar mass and this is believed to be typical for radical polymerization. Synthesized triple copolymer samples were studied as viscosity additives to petroleum oils and it found that depending on the demand may use these oils as viscosity additives by synthesizing any high molar mass copolymers with high yield.

Since synthesized copolymer samples are in the same level with polymethacrylate industrial additives in terms of improving viscosity-temperature properties of oils, the results showed their higher operating indicators in terms of thermal resistance and this case must be explained by stabilizing effect of styrene units.

\section{References}

1. Kaplan S.Z., Radzevenchuk I.F. Viscous additives and thickened oils. L.: Himiya Publ., 1982. 132 p. (In Russian).

2. Kuliev A.M. Chemistry and technology of additives to oils and fuels. Leningrad: Himiya Publ., 1985, 312 p. (In Russian).

3. Akhmedov A.I., Farzaliev V.M., Aliguliev R.M. Polymer additives and oils, Baku: Elm Publ., 2000, 175 p. (In Azerbaijan).

4. Akhmedov A.I. State of research on the synthesis of viscous additives in the republic. Azerbaydjanskoe Neftyanoe Khozyaystvo Azerbaijan Oil Industry. 2002, No. 4, pp. 3739.

5. Akhmedov A.I., Askerova Kh.A., Isakov E.U., Gamidova D.Sh. Synthesis of viscosity additives for lubricating oils by copolymerization of butyl methacrylate with allyl naphthenates. Neftepeperabotka $i$ Neftechimiya - Oil Processing and Pertochemistry. 2009, no. 5, pp. 31-33. (In

\section{Russian).}

6. Ahmadov A.I., Hamidova J.Sh., Isakov E.U., Adigozalova F.C. Synthesis of copolymers of allylnaphenates with styrene as viscosity additives. Azerbaijan Chemical Journal. 2009, no. 2, pp. 119-121.

7. Farzaliyev V.M., Ahmadov A.I., Hasanova E.I. Synthesis of butylmethacrylate-oallylphenol copolymers as viscosity additives to complex essential oils. AMEA-nin meruzeleri - Report of ANAS. 2009, no 6, pp. 79-83. (In Azerbaijan).

8. Kazimzadeh L.K., Hamidova D.Sh., Hasanova E.I. Co-oligomers of allyl ethers as viscosity additives. Mejdunarodniy Nauchniy Jurnal - International Scientific Journal "Young Scientist". 2019, no. 52 (290), pp. 309-312. (In Russian).

9. Preparative Organic Chemistry. / Edited by N.S. Wulfson. Moscow: Himiya Publ., 1964, pp. 440-450. 


\title{
ALLILLKAPRILAT-STIROL BIRGO POLIMERININ SINTEZI VЭ SÜRTKÜ YAĞLARINA ÖZLÜLÜK AŞQARI KIMI TODQIQI
}

\author{
C.Ş. Homidova, L.K. Kazımzado, E.İ. Hosonova, E.U. İsakov, S.S. Babayev \\ AMEA akad. Ә. Quliyev adına Aşqarlar Kimyası Institutu \\ AZ1029, Bakı şəh., Böyükşor şossesi, mahalla 2062 Tel.: (+9912)5149612 \\ e-mail: c.hamidova@mail.ru
}

Maqaladə kapril turşusunun allil efirinin - allilkaprilatın stirolla birga polimerinin padikal mexanizmi üzrə birga polimerlaşmasinin, prosesa asas amillarin - ilkin monomer qarışığının va inisiatorun tasirinin va birga polimerin sürtkü yağlarının tərkibində özlülük aşqarı kimi tadqiqinin naticalari verilmişdir. Müəyyən edilmişdir ki, sintez edilmiş birga polimer nümunalari yağların özlülük-temperatur xassalarini yaxşılaşdırmağa göro polialkilmetakrilat tipli sənaye aşqarları ila eyni səviyyado olduğu halda, termiki təsirlarə qarşı davamlılıqlarına görə onlardan daha yüksək istismar göstəricilarinə malikdirlar ki, bu hal isə stirol manqalarının stabillaşdirici tasiri ila izah olunmalıdır. Sintez olunmuş birga polimer nümunalarinin neft yağlarına özlülük aşqarları kimi tədqiqi göstərmişdir ki, tolabatdan asılı olaraq istənilon molekul kütlayə malik yüksək çıxımlı birgə polimerlər sintez edərək, bu yağlara özlülük aşqarı kimi istifadə etmək olar.

Açar sözlor: kapril turşusu, allil spirti, allilkaprinat, stirol, birga polimer, özlülük aşqarl, neft yağları

\section{СИНТЕЗ СОПОЛИМЕРОВ АЛЛИЛКАПРИЛАТА СО СТИРОЛОМ И ИССЛЕДОВАНИЕ ИХ В КАЧЕСТВЕ ВЯЗКОСТНЫХ ПРИСАДОК К СМАЗОЧНЫМ МАСЛАМ}

\author{
Д.Ш. Гамидова, Л.К. Кязимзаде, Э.И. Гасанова, Э. У. Исаков, С.С. Бабаев
}

Институт химии присадок им. акад. А.М. Кулиева Наџиональной АН Азербайджана AZ1029, Баку, Беюкшорское шоссе, квартал 2062. Тел .: (+9912) 5149612

e-mail: c.hamidova@mail.ru

В статье представлень результаты исследования сополимеризации аллилового эфира каприловой кислоть - аллилкаприлата со стиролом по радикальному механизму, влияния состава смесей исходных мономеров и расхода инициитора на проиесс, а также результать исследования синтезированного сополимера в качестве вязкостной присадки к смазочным маслам. Установлено, что образиы синтезированных полимерных соединений по улучшению вязкостно - температурных свойств находятся на одинаковом уровне с промышленными присадками полиалкилметакрилатного типа, но имеют более высокие эксплуатационные характеристики, чем промышленные присадки по устойчивости к термическим воздействиям, что обусловлено стабилизирующим действием стирольных звеньев. Исследование образцов синтезированных сополимеров в качестве присадок показало, что в зависимости от конкретных требований, предъявляемых к маслам, могут быть синтезированы полимерные соединения с различной молекулярной массой и высоким выходом для использования их в качестве вязкостной присадки к маслам.

Ключевые слова: каприловая кислота, аллиловый спирт, аллилкаприлат, стирол, сополимер, вязкостные присадки, нефтяные масла. 